\title{
Гендерные стереотипы в тувинских пословицах и поговорках"
}

\author{
Аида И. Егорова, Аграфена П. Кондакова \\ Северо-Восточный федеральный университет им. М. К. Аммосова, Российская Федерация, \\ Мария А. Кужугет \\ Тувинский государственный университет, Российская Федерация
}

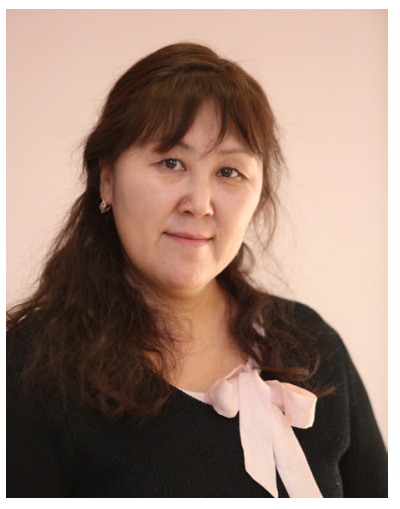

В статье представлено исследование традиционных гендерных стереотипов в тувинских паремиях и их оценке опрошенными респондентами - тувинцами. Использованы методы: интент-анализа с целью выявления интенций (скрытой направленности) пословиц и поговорок, шкала оценки гендерных стереотипов. Отобрано 75 пословиц и поговорок, содержащих описание мужского и женского поведения. Для последующей оценки и составления шкалы из них отобрано 45 паремий, отражающих гендерные стереотипы и социальное поведение мужчин и женщин. В июне 2018 г. опрошено 120 тувинцев обеих полов двух возрастных групп: от 18 до 35 лет, от 35 лет и старше.

В паремиях тувинцев достаточно подробно отражено содержание и четко прослеживается скрытая направленность гендерных стереотипов. В паремиях отражены традиционные семейно-родовые отношения, основанные на патриархальных установках, регламентации гендерных различий и дихотомизации мужского и женского. В мужских стереотипах, отраженных в тувинских пословицах, скрыты интенции: «Восхваление», «Оценка», «Наставление», «Совет», «Поучение». Интенции женских стереотипов тувинцев: «Наставление», «Оценка», «Восхваление», «Поучение», «Обличение».

Опрошенные тувинцы в цеелом согласны с традиционными представлениями о женском и мужском поведении и вполне допускают проявление сексизма в отношении к женщинам. Данные установки особенно выражены у мужчин и у людей старшего поколения. Существенных различий между половыми и возрастными выборками в оценке пословиц не обнаружено.

Ключевые слова: тувинский язык; паремия; пословица; поговорка; тувинский фольклор; гендерный стереотип; андроцентризм; андрократия

"Работа выполнена в рамках научного проекта № 18-013-00212 «Кросс-культурное исследование гендерных стереотипов народов Сибири и Северо-Востока России» при поддержке РФФИ.

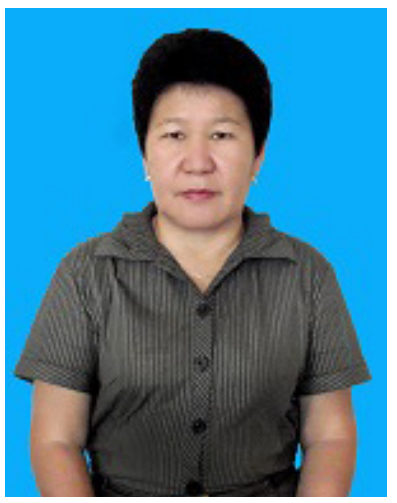

\section{Для цитирования:}

Егорова А. И., Кондакова А. П., Кужугет М. А. Гендерные стереотипы в тувинских пословицах и поговорках [Электронный ресурс] // Новые исследования Тувы. 2020 № 1. URL: https://nit.tuva.asia/nit/article/view/903 (дата обращения: дд.мм.гг.). DOI: 10.25178/nit.2020.1.2

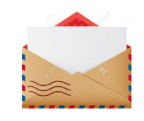

Егорова Аида Июньевна - кандидат психологических наук, директор Института психологии Северо-Восточного федерального университета им. М. К. Аммосова. Адрес: 677000, Россия, г. Якутск, ул. Белинского, д. 58. Тел.: +7 (4112) 49-67-53. Эл. адрес: aidaego@mail.ru ORCID ID: 0000-0002-7985-4134; Researcher ID: F-9556-2014

Кондакова Аграфена Петровна - кандидат психологических наук, заведующий кафедрой психологии и социальных наук Института психологии Северо-Восточного федерального университета им. М. К. Аммосова. Адрес: 677000, Россия, г. Якутск, ул. Белинского, д. 58. Тел.: +7 (4112) 49-67-53. Эл. адрес: agmaks@yandex.ru Researcher ID: W-7038-2019.

Кужугет Мария Амын-ооловна - заведующая литературным музеем Тувинского государственного университета. Адрес: 667000, Россия, г. Кызыл, ул. Ленина, д. 36. Тел.: +7 (923) 383-03-55. Эл. адрес: kuzhuget.m55@mail.ru Egorova Aida Iyunievna, Candidate of Psychology, Director, Institute of Psychology, M.K. Ammosov North-Eastern Federal University. Postal address: 58 Belinsky St., 677000 Yakutsk, Russian Federation. Tel.: +7 (4112) 49-67-53. Email: aidaego@mail.ru

Kondakova Agrafena Pavlovna, Candidate of Psychology, Chair, Department of Psychology and Social Sciences, Institute of Psychology, M.K. Ammosov North-Eastern Federal University. Postal address: 58 Belinsky St., 677000 Yakutsk, Russian Federation. Tel.: +7 (4112) 49-67-53. Email: agmaks@yandex.ru

Kuzhuget Maria Amyn-oolovna, Director, Literary Museum, Tuvan State University. Postal address: 36 Lenin St., 667000 Kyzyl, Russian Federation. Tel.: +7 (923) 383-03-55. Email: kuzhuget.m55@mail.ru 


\title{
Gender stereotypes in Tuvan proverbs and sayings"
}

\author{
Aida I. Egorova, Agrafena P. Kondakova \\ North-Eastern Federal University, Russian Federation, \\ Maria A. Kuzhuget \\ Tuvan State University, Russian Federation
}

\begin{abstract}
The article examines traditional gender stereotypes as they appear in Tuvan paroemias and the assessment of these paroemias by Tuvan respondents. The survey made use of the method of intent analysis to identify the intentions (hidden agendas) of proverbs and sayings, and also of the scale of assessment of gender stereotypes. For our study, we selected 75 proverbs and sayings containing a description of male and female behavior. To evaluate and compile the scale, the list was narrowed down to 45 paroemias reflecting gender stereotypes and social behavior of men and women. In June 2018, 120 Tuvans of both genders were surveyed, belonging to either of the two age groups - 18 to 35 and 36 and abover.

On the whole, Tuvan paremias reflect in detail the hidden intentions of gender stereotypes. The paremias present traditional family and tribal relations based on patriarchal attitudes, regulation of gender differences and dichotomization of male and female. Male stereotypes, as reflected in Tuvan proverbs, feature such hidden intentions as «Praise», «Evaluation», «Instruction», «Advice», «Teaching», while female Tuvan stereotypes focus on intentions like «Instruction», «Evaluation», «Praise», «Teaching», «Condemnation».

Respondents largely agree with the traditional views of male and female behavior and tend to be sexist to women. These trends are especially pronounced in men and in older people. There was no significant difference between the sex and age samples in the assessment of proverbs.
\end{abstract}

Keywords: Tuvan language; paroemia; proverbs; sayings gender stereotypes; male stereotypes; female stereotypes; androcentrism; androcracy

"The article has been written with the support of the Russian Foundation for Basic Research (project No. 18-013-00212, "A cross-cultural study of gender stereotypes among the peoples of Siberia and Russia's North-East”).

\section{For citation:}

Egorova A. I., Kondakova A. P. and Kuzhuget M. A. Gender stereotypes in Tuvan proverbs and sayings. The New Research of Tuva. 2020, no. 1 [online] Available at: https://nit.tuva.asia/nit/article/view/903 (access date ... ). DOI: 10.25178/ nit.2020.1.2

\section{Введение}

В условиях глобальных преобразований, трансформации традиционных культурных ценностей, разрушения моральных ориентиров, изменения жизненных приоритетов в большинстве обществ меняются представления о социальной роли мужчин и женщин, карьере, профессии, семье. Гендерные стереотипы поддерживают гендерную асимметрию в обществе, общественную мораль, иерархию ролей мужчин и женщин в обществе и семье, стабилизируют или дестабилизируют брачно-семейные отношения. Трансформация традиционных гендерных ролей и стереотипов существенно повлияла на усиление гендерной асимметрии, феминизации и андрогинизации общества, на превалирование унисексуальных установок во многих сферах общественной жизни, появление новых форм брачносемейных отношений, рост числа разводов и неполных семей, изменение репродуктивных установок, появление межэтнических браков и сложное отношение к ним в обществе (Доржу, 2019).

В поликультурном российском пространстве нет единой гендерной политики и модели, трансформационные процессы в области гендерных отношений протекают неодинаково в силу сложившихся религиозных и культурных традиций различных этнических сообществ. Изменение гендерных стереотипов в этнической культуре является ярким индикатором глубоких внутренних изменений ценностей, морального сознания и этнического самосознания, так как сфера брачно-семейной отношений наиболее подвержена регуляции религиозными и традиционными нормами культуры. Динамика изменения гендерных стереотипов в разных этнокультурных сообществах различается в зависимости от степени влияния религиозных традиций, нравов, обычаев, образа жизни, менталитета, межпоколенных и внутрисемейных отношений. Исследование гендерных стереотипов разных культур 
дает возможность для понимания и объяснения многих когнитивных схем и способов категоризации окружающего мира, в т. ч. взаимоотношений полов, специфики брачно-семейных и супружеских отношений, содержания идеалов маскулинности/фемининности, определения стратегии и модели гендерной социализации детей.

Теоретической основой нашего исследования явились работы в области современной этнической и кросс-культурной психологии гендера (Williams at al., 1982; Best, 2001; Берн, 2007; Lease, Montes, Baggett, 2012), гендерной психологии (Клёцина, 2009), гендерной психолингвистики (Телия, 1996; Кириллина, 1999). Современные исследования гендера в кросс-культурном ключе показывают, что, несмотря на универсальность основных параметров, гендерные стереотипы могут иметь специфику в зависимости от культуры. Этническая культура оказывает сильное влияние на содержание гендерных стереотипов, выдвигая специфические требования к поведению мужчин и женщин.

Гендерные стереотипы, репрезентированные в языковой системе, недостаточно изучены и представляют большой научный интерес. Гендерный код, заложенный в языковой системе, определяет не только модели и паттерны общения, но и нормы и стандарты мужского и женского поведения, существующие в обыденном сознании. Одним из важных источников информации о характере и содержании гендерных отношений являются паремии (пословицы, поговорки, предписания (экспектации), запреты (табу), обереги, краткие изречения, метафоры). Паремии как формы мифологического и обыденного сознания обладают признаками стандартизированности, схематизированности, экспрессивности, наличием оценочного и эмоционального компонентов. В паремиях в меткой и схематичной форме отражаются традиционные гендерные роли, психологические корни идеалов и стереотипов маскулинности и фемининности, запретов и предписаний мужского и женского поведения.

Объектом нашего большого исследования, которое выполнялось в 2018 г., явились тюркские народы Сибири: алтайцы, тувинцы, хакасы, якуты, долганы. В 2019 г. исследование было продолжено среди малочисленных народов, проживающих в Республике Саха (Якутия): юкагирах, чукчах, эвенах и эвенках (Егорова, Чочкина, Сарбашева, 2019¹). В проекте решается задача кросс-культурных различий в содержании гендерных стереотипов в зависимости от принадлежности к языковой группе и территориальной общности. В данной статье представлено исследование гендерных стереотипов тувинцев, содержащихся в паремиях.

Например, в мифологическом сознании тувинцев существовали различные архаические культы божеств, однако вопрос о существовании женского божества остается спорным. На вопрос о существовании женского божества Умай у тувинцев Л. П. Потапов пишет, что возможно в прошлом у тувинцев имело место почитание Умай, поскольку у бельтиров, которые являются частью тувинцев, данное божество им зафиксировано (Потапов, 1973).

Идеалы мужественности тувинцев отражены в образах сильных, метких, мудрых, трудолюбивых, добрых воинов-богатырей Алдай-Буучу, Мөге Шагаан-Толай, Мөге Баян-Далай и др. Также у тувинцев существовали андрогинные образы женщин-богатырок, связанные с периодом матриархата, когда женщины-матери занимали лидирующие позиции в родовом обществе. В тувинском эпосе такой образ представлен воинственной богатыркой, метким стрелком и наездницей Бора-Шээлей. В архаическом обществе женщины-богатырки представляли воинов, борцов и защитниц своего племени, народа от иноземных завоевателей и сочетали лучшие качества и идеалы женственности - свободолюбивые, сильные, отважные, мудрые, находчивые (Орус-оол, 1997: 10-38).

Сложившиеся в последующие века традиционные семейно-родовые отношения тувинцев были основаны на патриархальных установках и построены на регламентации гендерных различий, дихотомизации мужского и женского, иерархии статусов мужчин и женщин.

Целью нашего исследования является анализ гендерных стереотипов, содержащихся в тувинских пословицах и поговорках. В исследовании были использованы интент-анализ для выявления скрытой направленности (интенций) паремий и шкала оценки гендерных стереотипов при помощи пословиц и поговорок.

Из фольклорных и этнографических источников нами были отобраны 75 тувинских пословиц и поговорок, в которых в той или иной мере отражаются гендерные стереотипы, связанные с пред-

\footnotetext{
${ }^{1}$ Также в печати статья: Егорова, А. И., Тугужекова, В. Н., Каскаракова, 3. Е., Канзычакова, Н. Г. Гендерные стереотипы в хакасских и якутских паремия.
} 
писаниями и нормами поведения мужчин и женщин. Тувинские пословицы были отобраны из сборников (Хадаханэ, Саган-оол, 1966; Калзан, 1955; Курбатский, 2001), фразеологического словаря (Хертек, 1985), а также из научных изданий и статей, посвященных анализу паремий (Очерки тувинского фольклора ..., 1976); Кенин-Лопсан, 1987; Дьон-сэргэ ..., 2001; Байжанова, 2004).

Также для оценки степени согласия с гендерными стереотипами по факторам «Традиционализм» и «Сексизм», отраженными в тувинских паремиях, в июне 2018 г. проводился опрос среди населения г. Кызыла. В исследовании приняло участие 120 тувинцев - мужчин и женщин. Анализ результатов по выборке проводился по двум линиям: по полу и двум возрастным категориям респондентов (от 18 до 35 лет - 30 мужчин и 30 женщин, от 36 лет и старше - 30 мужчин и 30 женщин).

\section{Результаты интент-анализа}

Всего для анализа было выделено 14 интенций, в т. ч. 11 основных интенций: «Восхваление», «Благопожелание», «Оценка», «Поучение», «Утешение», «Наставление», «Совет», «Запрет», «Порицание», «Предостережение», «Дискредитация» и 3 отдельные интенции, относящиеся к основной интенции «Предостережение»: «Урезонивание», «Обличение», «Упрек» (см. рис. 1).

Первые три ранга интенций в тувинских пословицах заняли «Оценка», «Наставление» «Восхваление», далее следуют «Поучение», «Благопожелание», «Совет», «Обличение». В мужских стереотипах интенции «Восхваление», «Оценка», «Совет», «Поучение» встречаются чаще, а в женских - «Наставление», «Урезонивание», «Запрет», «Обличение», «Дискредитация», «Упрек» чаще.

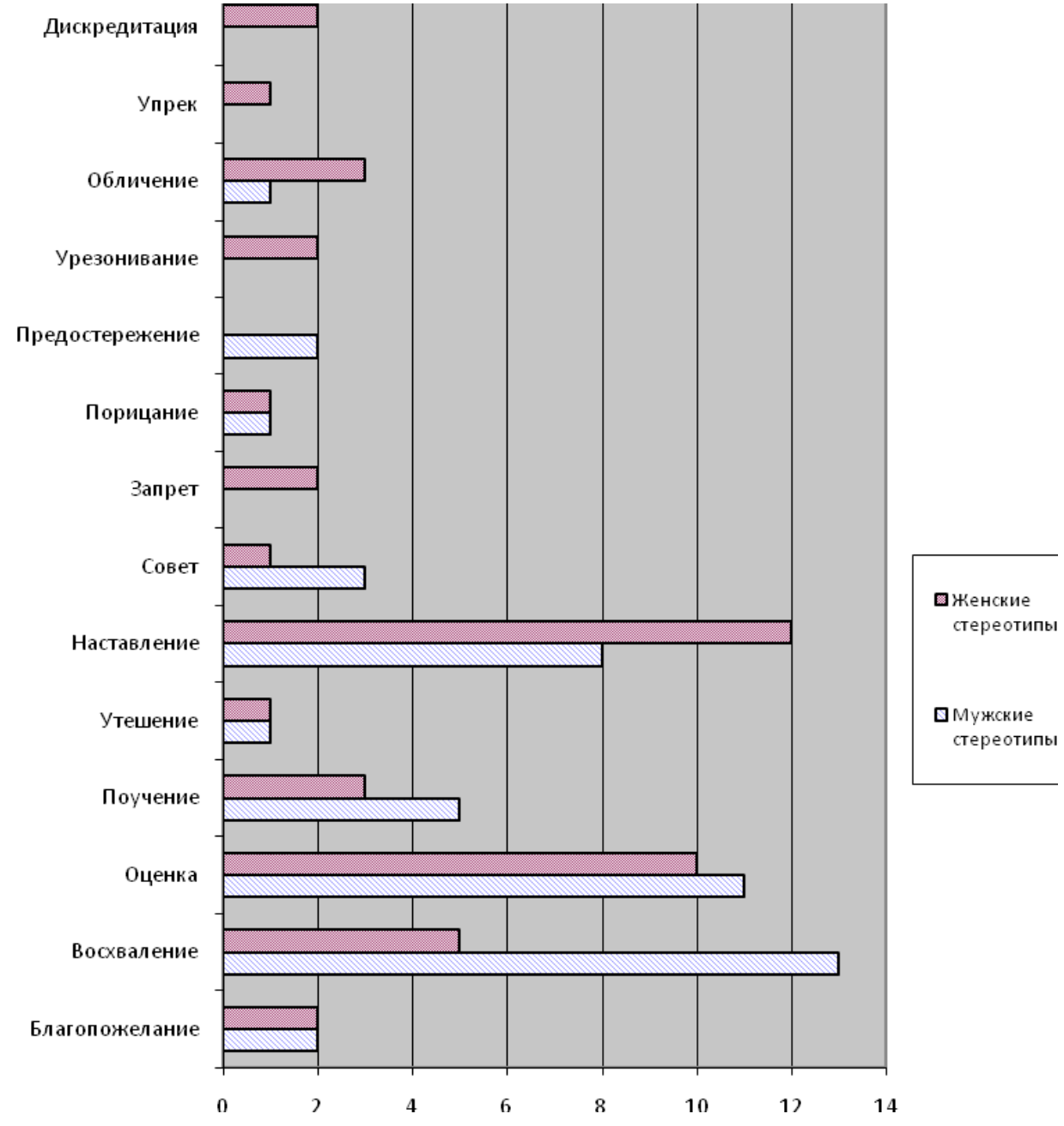

Рисунок 1. Частота встречаемости интенций в тувинских паремиях.

Fig.1. The frequency of intentions in Tuvan paroemias. 
Таким образом, очевидно, что в тувинских паремиях интенции, скрытые в мужских стереотипах, в целом благоприятные, что указывает на положительный образ мужчины, а паремии, связанные с женскими образами, содержат больше негативных интенций.

\section{Анализ гендерных стереотипов}

В тувинских пословицах и изречениях отражены андроцентрические установки со скрытой интенцией «Восхваление»:

Ада кижи оглун сактыр, алдын-доос кудуруун сактыр - Отец гордится сыном, а павлин - хвостом’1,

Авага ажы-төлу артык, аңчыга алды-киш артык - 'Дорог охотнику соболь черный, матери - сын, в мученьях рожденный',

Кайгал эрниң караа илдең - 'Молодца видно по глазам'.

Мужские стереотипы тувинцев тесно связаны с традиционными видами деятельности - скотоводством, охотой, рыболовством, заготовкой дров, постройкой жилища. В пословицах тувинского народа, отражающих идеалы маскулинности и мужские стереотипы, подчеркиваются такие качества как физическая сила, ловкость, меткость, выносливость, трудолюбие, способность переносить тяготы, воинственность, решительность:

Эзир куш шың бажында, эки эр чурт бажында - 'Смелый орел летает над тайгой, умный мужчина правит страной',

Эр - олуттуг, эзир - чиштиг - 'У мужчины - почет, у орла - добыча',

Кажары дилги-ле, кашпагайы дииң-не - 'Хитёр как лиса, ловок, как белка',

Эки аъдыңны суглуктуг суггарып өөрет, эки оглуңну кадыг ишке дадыктыр - 'Хорошего коня с уздой пить учи, хорошего сына тяжелой работой закаляй',

Аңчы кижи одар эндевес, айбычы кижи аал эндевес - 'Охотник знает, где зверь водится, гонец знает, где аал находится',

Аът болуру кулунундан, кижи болуру чажындан - 'Конь вырастает из жеребёнка, человеком становятся с детства',

Хүн херелдиг, күдээ дузалыг - 'Солнце тепло даёт, зять - подмогу’,

Хүрең-дайның маңын көөр, күдээзиниң күжүн көөр - 'У лошади надо ход узнать, у зятя надо силу посмотреть'.

В данных паремиях скрыты интенции «Восхваление», «Наставление», «Оценка».

В некоторых тувинских паремиях встречается «Предостережение», т. е. при воспитании мальчиков и юношей нужно придерживаться строгости:

Тоткан эник ээзин ээрер, доруккан оол иезин чаңччаар - 'Перекормлен щенок - на хозяина лает, перехвален сынок - он и мать обругает’,

Эр эндээр, эрик бустур - ‘Мужчина может ошибиться, берег - разрушиться’.

Ряд пословиц и изречений определяют позиции и роль отца, мужчины в семье:

Ада чокта эш чок дег, аъды чокта бут чок дег - ‘Без отца как без друга, без коня как без ног’,

Адалыг кижи чоргаар - ‘Горд тот, у кого есть отец’,

Ада турда, чон таныыр; аът турда, чер көөр - 'Если с отцом, то знакомится с людьми; если с конём, то знакомится с округой',

Адалыг оол томаанныг - 'У кого есть отец, у того спокойный нрав',

Ада орнун оол салгаар, аът орнун кулун салгаар - 'Место отца наследует сын, как жеребёнок - коня’.

В тувинских паремиях отражена тенденция к андрократии (патриархату), связанная с доминированием мужчин и подчинением женщин:

Чаражынга шай хайындырбас, чажынга аът өртевес - 'На красе чаю не сваришь, к косе коня не привяжешь',

Кыс кижи дөр бажынга олурбас, төре херээ кылбас - 'Женщина не садится на почетное место, не решает государственные дела',

\footnotetext{
${ }^{1}$ Пословицы даны с переводами из источников.
} 
Өикү бажын тавакка салбас, кыс кижиниң сөзұн херекке албас - 'Козьей головой не угощают, с бабьим словом не считаются',

Артык тенек агбайын мактаар, аңчы кижи боозун мактаар - 'Глупый муж жену хвалит, охотник свое ружье'.

Несмотря на наличие некоторых сексистских установок и тенденцию к андрократии, можно предположить, что тувинские женщины были относительно свободнее в своих решениях. М. Х. Маннайоол пишет, что «...в семейно-бытовой сфере авторитет тувинской женщины был велик. Согласно общепринятым правилам, морально-этическим нормам поведения тувинцев, к женщине относились с уважением и заботой. Это проявлялось в разных сферах семейной жизни. Долгом мужчины было помогать женщине в беде, оберегать ее, выполнять ее просьбы. На женщину никто не имел права поднять руку, оскорблять и обижать ее. Тот, кто обижал женщину, покрывал себя позором и заслуживал презрения. Если кто-либо из мужчин поступил грубо по отношению к женщине, то говорили: “Женщина неприкосновенна. Для него нет ничего святого, он даже женщину бьет” (Маннай-оол, 2002: 57).

В тувинских пословицах отражены запреты и обычаи экзогамного брака, когда жен брали из другого рода:

Кыштаг турда, мал белен, кыс турда, күдээ белен - 'Был бы зимник - скот найдётся, была бы дочь зять сыщется',

Даш октаан черинге чыдар, кыс берген черинге орар - 'Где камень бросил, там и лежит, куда дочь отдал, там век ей жить'.

В паремиях данной категории скрыты интенции: «Наставление», «Поучение», «Запрет», «Упрек».

Женские стереотипы, содержащиеся в паремиях, отражали взгляды о «нечистоте» и опасности женщины, в т. ч. о неполноценности и ограниченности женщины:

Кыс кижи дөр бажынга олурбас, төре херээ кылбас - 'Женщина не садится на почетное место, не решает государственные дела',

Өшкү бажын тавакка салбас, кыс кижиниң сөзүн херекке албас - 'Козьей головой не угощают, с бабьим словом не считаются',

Херээжок кижиниң бодалы ожуун долгандыр, эр кижиниң бодалы делегейни дескиндир - 'Мысли женщины вокруг очага, мысли мужчины вокруг света'.

Женские стереотипы тувинцев были связаны с умениями женщин шить, мастерить, рукодельничать:

Инези чидигде - шевер, хачызы чидигде - каас - 'В остроте иголки - наряд, в остроте ножниц - мастерство',

Уран кыс удазынга ораашпас - 'Искусная мастерица в нитках не запутается’,

Эки дарган эргээн какпас, уран кыс удазынга ораашпас - 'Хороший кузнец по пальцу не ударит, искусная швея нитки не запутает'.

В целом женские стереотипы в тувинских паремиях отличаются противоречивостью. С одной стороны подчеркиваются положительные качества женщин как скромность, доброжелательность, гордость:

Уруглуг болуру - улуг кежик, чаштыг болуру - чаагай кежик - 'Иметь дочь - большое богатство, иметь сына - великое богатство',

Күдээниң күжү - хүндүлээчелинде, келинниң чаражы - томаанныында - 'Сила зятя - в его доброжелательности, сила невестки - в её скромности',

с другой стороны - изобличаются такие недостатки женского характера как скупость, болтливость, сварливость:

Хопчу кадын - сааскан, хоптак хаан - каарган - 'Ханша болтливая - сорока крикливая, хан прожорливый как черный ворон',

Демниг сааскан теве тудуп чиир - 'Много сорок, сообща, и верблюда съедят',

Калбак кезек - от чуду, харам кадай - өг чуду - 'Толстое полено огонь гасит, скупая хозяйка дом срамит',

Харам кадай - өг чуду - 'Скупая жена - позор для юрты'.

В данных паремиях скрыты интенции: «Наставление», «Упрек», «Обличение». 
Важной ценностью в традиционном сознании тувинцев является брачное состояние и создание семьи, в тувинских паремиях осуждается безбрачие, как мужское, так и женское:

Чааскаанда кээргенчиг, эштигде - кежиктиг - 'Одинокий человек жалок, человек в паре - счастлив'.

В данной паремии скрыта интенция «Наставление».

Таким образом, можно отметить, что в паремиях в полной мере отражены гендерные стереотипы. Скрытыми интенциями мужских стереотипов тувинцев являются «Восхваление», «Оценка», «Наставление», «Поучение» и «Совет», а женских стереотипов - «Наставление», «Оценка», «Восхваление», «Обличение» и «Поучение».

\section{Результаты оценки гендерных стереотипов}

В целях изучения степени выраженности традиционализма и сексизма в гендерных стереотипах нами была разработана шкала оценки пословиц и поговорок на тувинском языке. Методом экспертной оценки из 75 пословиц на тувинском языке для включения в инструментарий было отобрано 48.

Список пословиц предъявлялся испытуемым одновременно на двух языках: тувинском и русском ${ }^{1}$. Оценка пословиц проводилась по 5-балльной шкале. Максимальное согласие с утверждением оценивалось в 5 баллов, абсолютное несогласие - в 1 балл.

Всего из 48 пословиц 17 отражали мужские стереотипы, 21 - женские стереотипы, 10 - как мужские, так и женские стереотипы. Все пословицы и поговорки были отнесены к одной из 9 шкал ${ }^{2}$, первые 5 шкал объединены в фактор «Традиционализм», следующие 4 шкалы - в фактор «Сексизм». По каждой шкале подсчитывалось среднее значение по выборкам. При обработке различий между выборками применялся непараметрический метод углового преобразования Фишера (ф) и критерий Манна-Уитни (U).

Фактор «Традиционализм» включал шкалу «Традиционная мужественность» (ТМ), отражающую мужские стереотипы, представления о мужском поведении; шкалу «Традиционная женственность» (ТЖ), включающую женские стереотипы, представления о женском поведении; шкалу «Гендерная поляризация» (ГП), противопоставляющую мужские и женские роли, взаимоисключающую правила мужского и женского поведения; шкалу «Мужские и женские роли в семье» (МЖРС), представляющую традиционные семейные роли как мужчин, так и женщин; шкалу «Мужские роли в семье» (МРС) и шкалу «Женские роли в семье» (ЖРС).

Фактор «Сексизм» включал шкалу «Андроцентризм» (А), отражающую идеализированное представление о мужском; шкалу «Доброжелательный сексизм» (ДС), подчеркивающую идеальные

\footnotetext{
1 Все опрошенные владели тувинским языком, но по данной методике на других этнических выборках стимульный материал предъявлялся на 2-х языках во избежание случаев, когда могли в выборку попасть лица, не владеющие ТЯ. В случае с тувинцами мы были приятно удивлены, что все владеют родным языком и даже с нами - исследователями из других регионов - говорили на тувинском. Совершенно иная ситуация была с хакасами

${ }^{2}$ Методика включала 9 шкал: Фактор «Традиционализм»: Шкала 1. Традиционная мужественность (ТМ) - мужские стереотипы, представления о мужском поведении; Шкала 2. Традиционная женственность (ТЖ) - женские стереотипы, представления о женском поведении; Шкала 3. Гендерная поляризация (половой диморфизм) (ГП) - противопоставление мужских и женских ролей, взаимоисключение правил мужского и женского поведения; Шкала 4. Мужские и женские роли в семье (МЖРС) - традиционные гендерные роли в семье, представления о семейной роли мужчин и женщин; Субшкала 4.1. Мужские роли в семье (МРС); Субшкала 4.2. Женские роли в семье (ЖРС); Субшкала 4.3. Отношение к безбрачию, одиночеству (ОБ) - традиционное подчеркивание ценности семьи, детоцентризм, осуждение безбрачия. Фактор «Сексизм»: Шкала 5. Сексизм - предубеждение против лиц определенного пола, основанное на идеологии патриархата (С); Субшкала 5.1. Андроцентризм (гегемонная маскулинность) (А); представление о мужском как о норме, стандарте; Субшкала 5.2. Доброжелательный сексизм (ДС); подчеркивание и идеализация отдельных качеств женщин; Субшкала 5.3. Амбивалентный сексизм (АС) - одновременная идеализация и осуждение отдельных качеств мужчин и женщин; Субшкала 5.4. Враждебный сексизм по отношению к мужчинам (BCM) - принижение и осуждение отдельных качеств мужчин; Субшкала 5.5. Враждебный сексизм по отношению к женщинам (ВСЖ) принижение и осуждение отдельных качеств женщин; Шкала 6. Андрократия (патриархат) (АП) - социальный конструкт, в котором власть в семье полностью принадлежит мужчине, отцу; женщина не имеет прав и рассматривается как объект куплипродажи; Субшкала 6.1. Доминирование мужчин/подчинение женщин (ДП); Субшкала 6.2. Экзогамный брак (ЭБ); Субшкала 6.3. Калым (К); Субшкала 6.4. Умыкание (У); Субшкала 6.5. Избегание (И).
} 
качества женщин; шкалу «Враждебный сексизм по отношению к женщинам» (ВСЖ), отражающую патриархальные взгляды на природу женщин и шкалу «Экзогамный брак» (ЭБ).

Средние оценки по факторам по всей выборке показывают, что опрошенные, в целом, согласны с традиционными представлениями о женском и мужском поведении, и вполне допускают проявление сексизма в отношении к женщинам, что особенно выражено у мужчин и у лиц зрелого возраста (см. puc. 2).

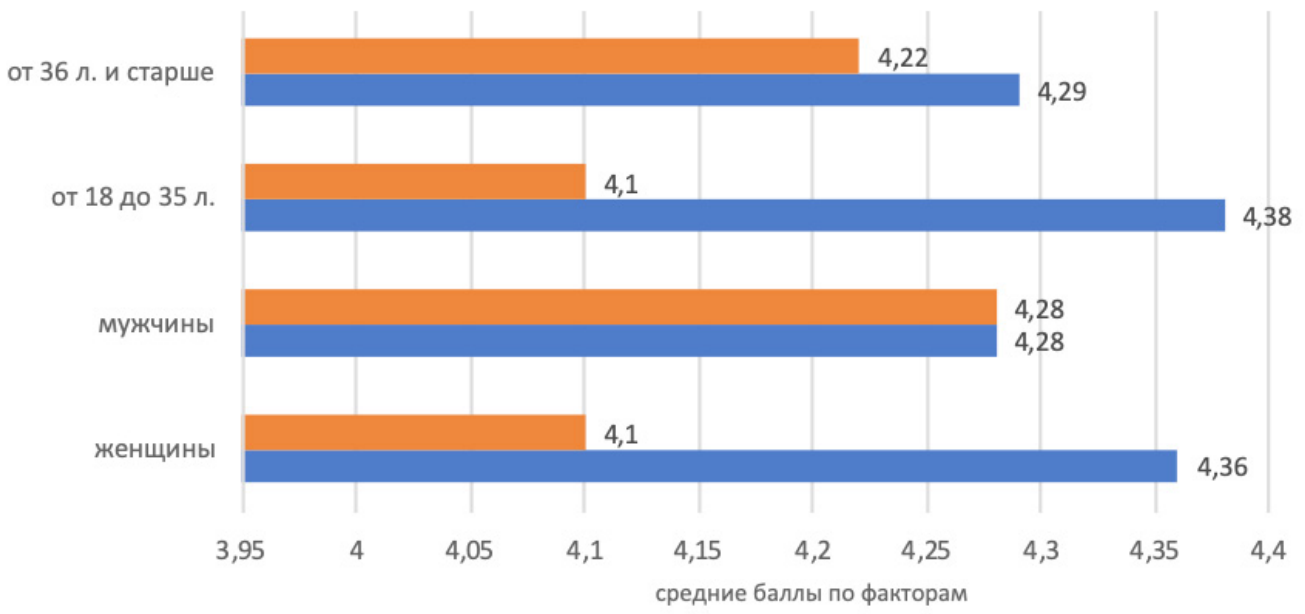

Рис. 2. Средние баллы по факторам «Сексизм» и «Традиционализм» у мужчин/женщин тувинцев от 18 до 35 л. и старше 36 лет.

Fig. 2. Average scores in the "Sexism" and "Traditionalism" factors among male and female Tuvans aged 18-35 and above 36.

Мужские и женские оценки. В среднем оценки пословиц у мужчин составили 4,33 балла, у женщин 4,31 балл.

У мужчин более высокие оценки оказались по шкалам: «Андроцентризм» (А), «Враждебный сексизм по отношению к женщинам» (ВСЖ), «Мужские роли в семье» (МРС) и «Экзогамный брак» (ЭБ).

У женщин более высокие оценки оказались по шкалам: «Доброжелательный сексизм» (ДС), «Традиционная мужественность» (ТМ), «Традиционная женственность» (ТЖ), «Гендерная поляризация» (ГП) и «Мужские и женские роли в семье» (МЖРС) (см. рис. 3).

6.2. Экзогамный брак (ЭБ)

5.5. Вражд. сексизм по отн. к женщинам (ВСж)

5.2. Доброжелательный сексизм (ДС)

5.1. Андроцентризм (A)

4.2. Женские роли в семье (ЖРС)

4.1.Мужсие роли в семье (МРC)

4. Мужские и женские роли в семье (МЖРС)

3. Гендерная поляризация (ГП)

2.Традционная женственность (ТЖ)

1.Традиционная мужественность (ТМ)

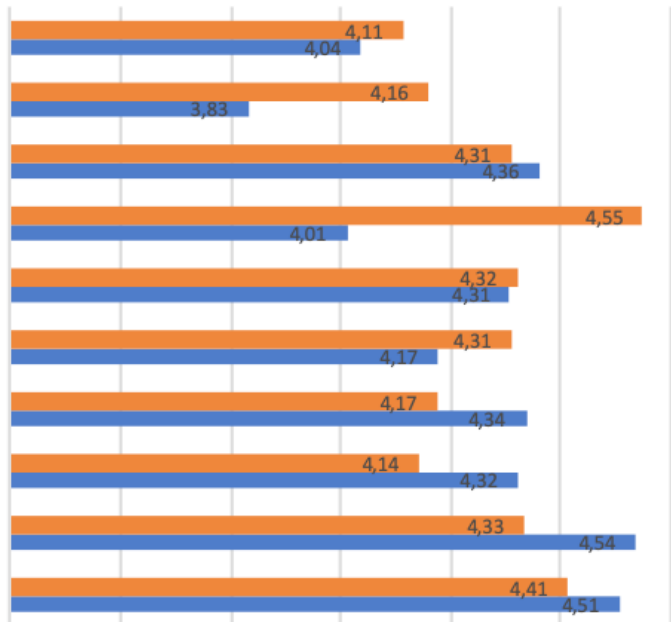

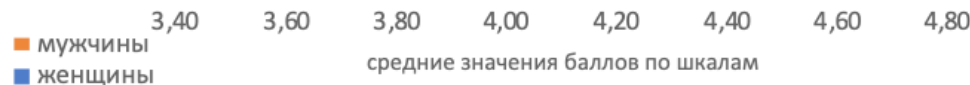

Pис. 3. Средние баллы мужчин и женщин тувинцев по шкалам.

Fig. 3. Average scores of male and female Tuvans along a variety of scales. 
Испытуемые обеих полов оказались согласованными в высокой оценке пословиц категории «Традиционная мужественность», «Мужские и женские роли в семье», «Женские роли в семье» (см. табл. 1).

Таблица 1. Пословицы с максимально выраженным согласием мужчин и женщин тувинцев.

Table 1. Proverbs which get the highest support from male and female Tuvans.

\begin{tabular}{|c|c|c|c|}
\hline \multicolumn{2}{|c|}{ Мужчины тувинцы $(n=60)$} & \multirow{2}{*}{$\begin{array}{c}\text { Шкалы } \\
\text { TM }\end{array}$} & \multirow{2}{*}{$\begin{array}{c}\text { Cp. } \\
\text { балл } \\
4,74\end{array}$} \\
\hline $\begin{array}{l}\text { Аът болуру кулунундан, кижи болуру } \\
\text { чажындан }\end{array}$ & $\begin{array}{l}\text { Конь вырастет из жеребенка, человеком } \\
\text { становятся с детства }\end{array}$ & & \\
\hline $\begin{array}{l}\text { Ада кижи оглун сактыр, алдын-доос } \\
\text { кудуруун сактыр }\end{array}$ & Отец гордится сыном, а павлин - хвостом & A & 4,71 \\
\hline $\begin{array}{l}\text { Ава болуру - аас-кежик, ада } \\
\text { болуру - алдар-хүнду }\end{array}$ & $\begin{array}{l}\text { Быть матерью - счастье, быть отцом - } \\
\text { слава, уважение }\end{array}$ & МЖРС & 4,71 \\
\hline Күжүр ава - хүн караа дег эргим & Милая мама - как солнечный луч дорога & ЖРС & 4,71 \\
\hline $\begin{array}{l}\text { Эки авдыңны суглуктуг сугzарып } \\
\text { өөрет, эки оглуңну кадыг ишке } \\
\text { дадыктыр }\end{array}$ & $\begin{array}{l}\text { Хорошего коня с уздой пить учи, хорошего } \\
\text { сына тяжелой работой закаляй }\end{array}$ & $\mathrm{TM}$ & 4,66 \\
\hline $\begin{array}{l}\text { Чаражынга шай хайындырбас, ча- } \\
\text { жынга аът өртевес }\end{array}$ & $\begin{array}{l}\text { На красе чаю не сваришь, к косе коня не } \\
\text { привяжешь }\end{array}$ & ВСЖ & 4,62 \\
\hline $\begin{array}{l}\text { Хатчыл черниң ыяжы илдең, кайгал } \\
\text { эрниң караа илдең }\end{array}$ & $\begin{array}{l}\text { Ветреное место узнают по деревьям, } \\
\text { удалого молодца - по глазам }\end{array}$ & $\mathrm{TM}$ & 4,60 \\
\hline $\begin{array}{l}\text { Ада орнун оол салгаар, абт орнун } \\
\text { кулун салгаар }\end{array}$ & $\begin{array}{l}\text { Место отца наследует сын, как жеребе- } \\
\text { нок - коня }\end{array}$ & MPC & 4,60 \\
\hline $\begin{array}{l}\text { Ада чокта - чартык өскүс, ава } \\
\text { чокта -бүдүн өскүс }\end{array}$ & $\begin{array}{l}\text { Без отца полусирота, без матери - круглая } \\
\text { сирота }\end{array}$ & МЖРС & 4,60 \\
\hline $\begin{array}{l}\text { Ава кижи төлүм дээр, ажы-төлү } \\
\text { шөлүм дээр }\end{array}$ & Думы матери о детях, мысли детей в степи & ЖРС & 4,55 \\
\hline & Женщины тувинки $(n=60)$ & & \\
\hline $\begin{array}{l}\text { Аът болуру кулунундан, кижи болуру } \\
\text { чажындан }\end{array}$ & $\begin{array}{l}\text { Конь вырастает из жеребенка, человеком } \\
\text { становятся с детства }\end{array}$ & $\mathrm{TM}$ & 4,90 \\
\hline $\begin{array}{l}\text { Булут аразындан хүн караа чылыг, } \\
\text { улус аразындан ава караа чымчак }\end{array}$ & $\begin{array}{l}\text { Среди облаков лучи солнца теплее, среди } \\
\text { людей глаза матери ласковее }\end{array}$ & ЖРС & 4,80 \\
\hline Күжүр ава - хүн караа дег эргим & Милая мама - как солнечный луч дорога & ЖРС & 4,78 \\
\hline $\begin{array}{l}\text { Ава болуру - аас-кежик, ада } \\
\text { болуру - алдар-хүнду }\end{array}$ & $\begin{array}{l}\text { Быть матерью - счастье, быть отцом - } \\
\text { слава, уважение }\end{array}$ & МЖРС & 4,72 \\
\hline $\begin{array}{l}\text { Чаражынга шай хайындырбас, ча- } \\
\text { жынга аът өртевес }\end{array}$ & $\begin{array}{l}\text { На красе чаю не сваришь, к косе коня не } \\
\text { привяжешь }\end{array}$ & ВСЖ & 4,72 \\
\hline Авазы хүн болза, ачазы ай болур & Если солнце - мать, отец - луна & МЖРС & 4,71 \\
\hline $\begin{array}{l}\text { Ада чокта - чартык өскүс, ава } \\
\text { чокта -бүдүн өскүс }\end{array}$ & $\begin{array}{l}\text { Без отца полусирота, без матери - круглая } \\
\text { сирота }\end{array}$ & МЖРС & 4,70 \\
\hline
\end{tabular}




\begin{tabular}{|l|c|c|c|}
\hline $\begin{array}{l}\text { Эге бениң куну семис, эки иениң } \\
\text { төлү эрес }\end{array}$ & $\begin{array}{c}\text { У молодой кобылы жеребенок справный, } \\
\text { у хорошей матери ребенок бойкий }\end{array}$ & ТМ & 4,68 \\
\hline
\end{tabular}

Прим.: значение средних оценок: от 5 до 4 - полностью согласен, от 2 до 1 - не согласен.

В список пословиц с наименьшей степенью согласия были включены пословицы с вариантами ответа «Затрудняюсь ответить», оценок ниже двух баллов ни в одной выборке тувинцев не обнаружено (табл. 2). В целом, как мужчины, так и женщины не согласны с пословицами категории «Враждебный сексизм по отношению к женщинам» (ВСЖ).

Таблица 2. Пословицы с минимально выраженным согласием мужчин и женщин тувинцев.

Table 2. Proverbs which get the lowest support from male and female Tuvans.

\begin{tabular}{|c|c|c|c|}
\hline \multicolumn{2}{|c|}{ Мужчины тувинцы $(n=60)$} & Шкалы & $\begin{array}{c}\text { Сp. } \\
\text { балл }\end{array}$ \\
\hline $\begin{array}{l}\text { Иезин «Инээм» дээр, адазын } \\
\text { «аъдымм» дээр }\end{array}$ & $\begin{array}{l}\text { Мать сравнивают с коровой, а отца - с } \\
\text { конем }\end{array}$ & МЖРС & 3,62 \\
\hline Сен дизе уруу, чемелезе кадайы & $\begin{array}{l}\text { Дочку свою ругает, лишь свою жену все } \\
\text { укоряет }\end{array}$ & MPC & 3,76 \\
\hline $\begin{array}{l}\text { Ада сөзу - амыдырал, ие сөзү - } \\
\text { ажыл-иш }\end{array}$ & Слово отца - жизнь, слово матери - работа & МЖРС & 3,81 \\
\hline $\begin{array}{l}\text { Өшкү бажын тавакка салбас, кыс } \\
\text { кижиниң сөзүн херекке албас }\end{array}$ & $\begin{array}{l}\text { Козьей головой не угощают, с бабьим словом } \\
\text { не считаются }\end{array}$ & ВСЖ & 3,86 \\
\hline $\begin{array}{l}\text { Кыс кижи дөр бажынга олурбас, } \\
\text { төре херээ кылбас }\end{array}$ & $\begin{array}{l}\text { Женщина не садится на почетное место и } \\
\text { не решает государственные дела }\end{array}$ & ВСЖ & 3,88 \\
\hline \multicolumn{4}{|c|}{ Женщины тувинки $(n=60)$} \\
\hline $\begin{array}{l}\text { Кыс кижи будун силгивес, халымак, } \\
\text { сиилеңин көргүспес }\end{array}$ & $\begin{array}{l}\text { Девушке нельзя качать ногою, нельзя } \\
\text { показывать ветреность и распущенность } \\
\text { свою }\end{array}$ & ВСЖ & 3,44 \\
\hline $\begin{array}{l}\text { Кыс кижи дөр бажынга олурбас, } \\
\text { төре херээ кылбас }\end{array}$ & $\begin{array}{l}\text { Женщина не садится на почетное место и } \\
\text { не решает государственные дела }\end{array}$ & ВСЖ & 3,45 \\
\hline $\begin{array}{l}\text { Өшкү бажын тавакка салбас, кыс } \\
\text { кижиниң сөзүн херекке албас }\end{array}$ & $\begin{array}{l}\text { Козьей головой не угощают, с бабьим словом } \\
\text { не считаются }\end{array}$ & ВСЖ & 3,47 \\
\hline Сен дизе уруу, чемелезе кадайы & $\begin{array}{l}\text { Дочку свою ругает, лишь свою жену все } \\
\text { укоряет }\end{array}$ & MPC & 3,56 \\
\hline $\begin{array}{l}\text { Иезин «инээм» дээр, адазын } \\
\text { «аъдымм дээр }\end{array}$ & $\begin{array}{l}\text { Мать сравнивают с коровой, а отца - с } \\
\text { конем }\end{array}$ & МЖРС & 3,65 \\
\hline
\end{tabular}

Прим.: значение средних оценок: от 5 до 4 - полностью согласен, от 2 до 1 - не согласен.

Значимые различия между женщинами и мужчинами обнаружены при оценивании следующих пословиц:

Авага ажы-төлу артык, аңчыга алды-киш артык - 'Дорог охотнику соболь черный, матери - сын, в мученьях рожденный’ (U=0,016),

Хатчыл черниң ыяжы илдең, кайгал эрниң караа илдең - 'Ветреное место узнают по деревьям, удалого молодца - по глазам’ (U=0,047),

Кыс кижи будун силгивес, халымак, сиилеңин көргүспес - 'Девушке нельзя качать ногою, нельзя показывать ветреность и распущенность свою' (U=0,006),

где мужчины больше проявляют согласие с данными утверждениями. Женщины, в отличие от мужчин, согласны с тем, что 
НОВЫЕ ИССЛЕДОВАНИЯ ТУВЫ

Www.nit.tuva.asia

Авазы хүн болза, ачазы ай болур - 'Если солнце - мать, отец - луна' (U=0,000).

В целом, мужчины выражают больше согласия с пословицами, отражающими гендерные стереотипы, чем женщины.

Возрастные различия. В среднем оценки пословиц у молодых тувинцев составили 4,32 балла, у тувинцев зрелого возраста $-4,27$ балла.

Если смотреть по факторам (рис. 4), то у молодых тувинцев выше оценки по фактору «Традиционализм», а у тувинцев зрелого возраста выше оценки по фактору «Сексизма». Тувинцы молодого возраста более высокие оценки продемонстрировали по шкалам: «Доброжелательный сексизм» (ДС), «Традиционная мужественность» (ТМ), «Традиционная женственность» (ТЖ), «Гендерная поляризация» (ГП) и «Мужские и женские роли в семье» (МЖРС). Тувинцы зрелого возраста дали более высокие оценки по шкалам: «Андроцентризм» (А), «Враждебный сексизм по отношению к женщинам» (ВСЖ), «Мужские роли в семье» (МРС) и «Женские роли в семье» (ЖРС).

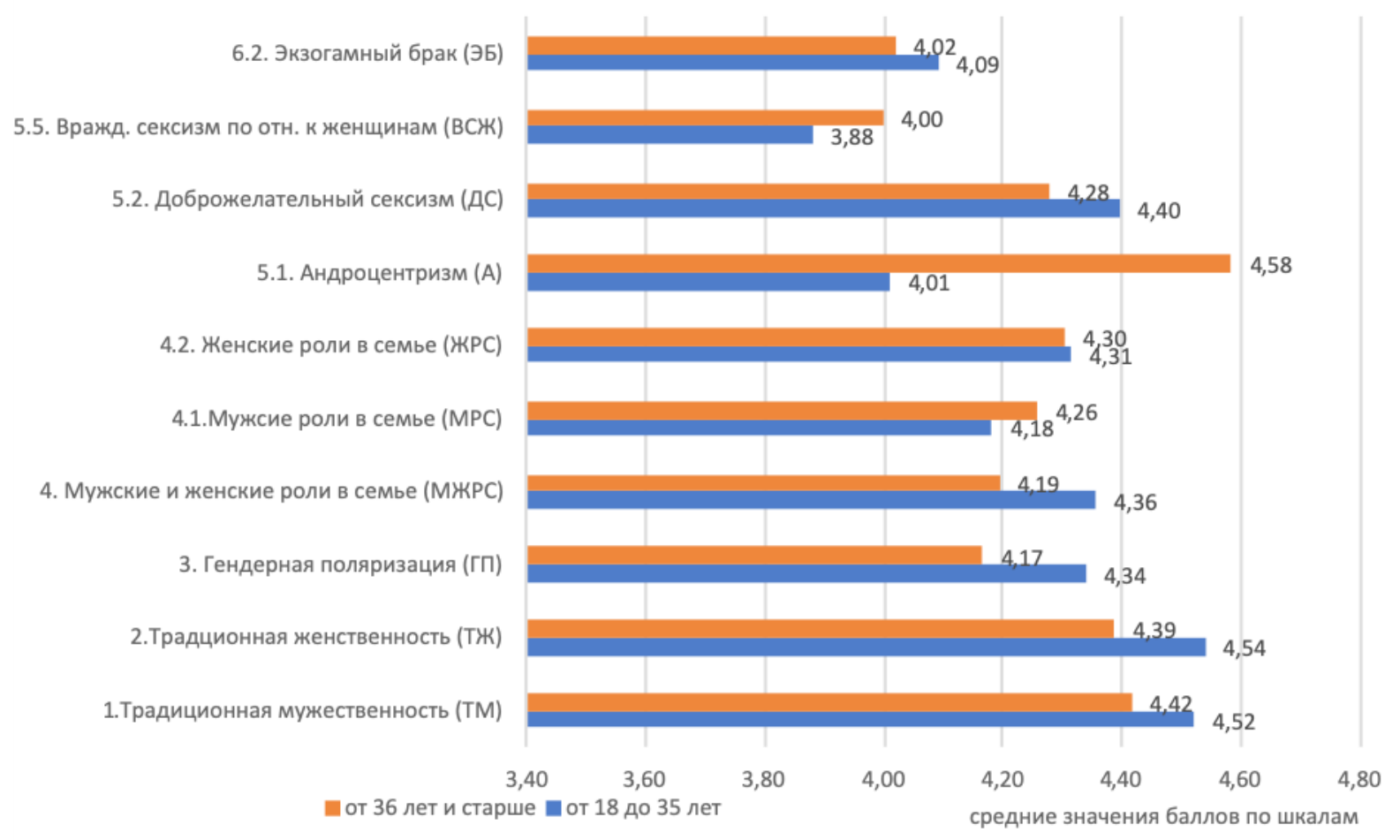

Рис. 4. Средние баллы тувинцев от 18 до 35 лет и от 36 лет и старше по шкалам.

Fig. 4. Average scores among Tuvans aged 18-35, and 36 and above, according to a variety of scales.

Анализ оценок по возрастным группам свидетельствует о том, что у молодых тувинцев наиболее часто высокие оценки встречались по шкалам: «Женские роли в семье» (ЖРС), «Мужские и женские роли в семье» (МЖРС), у тувинцев зрелого возраста по шкалам: «Традиционная мужественность» (ТМ), «Мужские роли в семье» (МРС), «Женские роли в семье» (ЖРС), «Мужские и женские роли в семье» (МЖРС) (табл. 3).

Таблица 3. Пословицы с максимально выраженным согласием тувинцев молодого и зрелого возраста.

Table 3. Proverbs which get the highest support from younger and older Tuvans.

\begin{tabular}{|c|c|c|c|}
\hline \multicolumn{2}{|c|}{ Тувинцы молодого возраста (от 18 до 35 лет) } & Шкалы & $\begin{array}{l}\text { Сp. } \\
\text { балл }\end{array}$ \\
\hline $\begin{array}{l}\text { Абт болуру кулунундан, кижи } \\
\text { болуру чажындан }\end{array}$ & $\begin{array}{l}\text { Конь вырастает из жеребенка, человеком } \\
\text { становятся с детства }\end{array}$ & $\mathrm{TM}$ & 4,84 \\
\hline Күжүр ава - хүн караа дег эргим & Милая мама - как солнечный луч, дорога & ЖРС & 4,78 \\
\hline
\end{tabular}




\begin{tabular}{|c|c|c|c|}
\hline $\begin{array}{l}\text { Булут аразындан хүн караа чылыг, } \\
\text { улус аразындан ава караа чымчак }\end{array}$ & $\begin{array}{l}\text { Среди облаков лучи солнца теплее, среди } \\
\text { людей глаза матери ласковее }\end{array}$ & ЖРС & 4,73 \\
\hline $\begin{array}{l}\text { Ава болуру - аас-кежик, ада } \\
\text { болуру-алдар-хүндү }\end{array}$ & $\begin{array}{l}\text { Быть матерью - счастье, быть отцом - } \\
\text { слава, уважение }\end{array}$ & МЖРС & 4,71 \\
\hline $\begin{array}{l}\text { Чаражынга шай хайындырбас, } \\
\text { чажынга абт өртевес }\end{array}$ & $\begin{array}{l}\text { На красе чаю не сваришь, к косе коня не } \\
\text { привяжешь }\end{array}$ & ВСЖ & 4,67 \\
\hline $\begin{array}{l}\text { Ада кижи оглун сактыр, алдын- } \\
\text { доос кудуруун сактыр }\end{array}$ & Отец гордится сыном, а павлин - хвостом & A & 4,67 \\
\hline $\begin{array}{l}\text { Ада чокта - чартык өскүс, ава } \\
\text { чокта - бүдүн өскүс }\end{array}$ & $\begin{array}{l}\text { Без отца полусирота, без матери - круглая } \\
\text { сирота }\end{array}$ & МЖРС & 4,78 \\
\hline $\begin{array}{l}\text { Эки авдыңны суглуктуг суггарып } \\
\text { өөрет, эки оглуңну кадыг ишке } \\
\text { дадыктыр }\end{array}$ & $\begin{array}{l}\text { Хорошего коня с уздой пить учи, хорошего } \\
\text { сына тяжелой работой закаляй }\end{array}$ & $\mathrm{TM}$ & 4,61 \\
\hline $\begin{array}{l}\text { Авыралдыг чүве - ава, аянныг } \\
\text { эди-сава }\end{array}$ & $\begin{array}{l}\text { Самый благодетельный человек - мать, } \\
\text { хорошая вещь - пиала }\end{array}$ & ЖРС & 4,61 \\
\hline \multicolumn{4}{|c|}{ Тувинцы зрелого возраста (от 36 лет и старше) } \\
\hline $\begin{array}{l}\text { Авт болуру кулунундан, кижи } \\
\text { болуру чажындан }\end{array}$ & $\begin{array}{l}\text { Конь вырастет из жеребенка, человеком } \\
\text { становятся с детства }\end{array}$ & $\mathrm{TM}$ & 4,90 \\
\hline $\begin{array}{l}\text { Эки авдыңны суглуктуг суггарып } \\
\text { өөрет, эки оглуңну кадыг ишке } \\
\text { дадыктыр }\end{array}$ & $\begin{array}{l}\text { Хорошего коня с уздой пить учи, хорошего } \\
\text { сына тяжелой работой закаляй }\end{array}$ & $\mathrm{TM}$ & 4,85 \\
\hline $\begin{array}{l}\text { Булут аразындан хүн караа чылыг, } \\
\text { улус аразындан ава караа чымчак }\end{array}$ & $\begin{array}{l}\text { Среди облаков лучи солнца теплее, среди } \\
\text { людей глаза матери ласковее }\end{array}$ & ЖРС & 4,85 \\
\hline $\begin{array}{l}\text { Кускун кара-даа болза, төлүнге } \\
\text { ынак }\end{array}$ & Ворон, хоть черный, воронят своих любит & ЖРС & 4,85 \\
\hline $\begin{array}{l}\text { Ада кижи оглун сактыр, алдын- } \\
\text { доос кудуруун сактыр }\end{array}$ & Отец гордится сыном, а павлин - хвостом & A & 4,80 \\
\hline $\begin{array}{l}\text { Эге бениң куну семис, эки иениң } \\
\text { төлү эрес }\end{array}$ & $\begin{array}{l}\text { У молодой кобылы жеребенок справный, у } \\
\text { хорошей матери ребенок бойкий }\end{array}$ & $\mathrm{TM}$ & 4,80 \\
\hline $\begin{array}{l}\text { Чаражынга шай хайындырбас, } \\
\text { чажынга аът өртевес }\end{array}$ & $\begin{array}{l}\text { На красе чаю не сваришь, к косе коня не } \\
\text { привяжешь }\end{array}$ & ВСЖ & 4,80 \\
\hline $\begin{array}{l}\text { Ада чокта - чартык өскүс, ава } \\
\text { чокта - бүдүн өскүс }\end{array}$ & $\begin{array}{l}\text { Без отца полусирота, без матери - круглая } \\
\text { сирота }\end{array}$ & МЖРС & 4,80 \\
\hline $\begin{array}{l}\text { Инези чидигде - шевер, хачызы } \\
\text { чидигде - каас }\end{array}$ & $\begin{array}{l}\text { В остроте иголки - наряд, в остроте } \\
\text { ножниц - мастерство }\end{array}$ & ТЖ & 4,75 \\
\hline $\begin{array}{l}\text { Ава болуру - аас-кежик, ада } \\
\text { болуру - алдар-хүндү }\end{array}$ & $\begin{array}{l}\text { Быть матерью - счастье, быть отцом - } \\
\text { слава, уважение }\end{array}$ & МЖРС & 4,75 \\
\hline $\begin{array}{l}\text { Авыралдыг чүве - ава, аянныг } \\
\text { эди-сава }\end{array}$ & $\begin{array}{l}\text { Самый благодетельный человек - мать, } \\
\text { хорошая вещь - пиала }\end{array}$ & ЖРС & 4,65 \\
\hline Күжүр ава - хүн караа дег эргим & Милая мама - как солнечный луч, дорога & ЖРС & 4,60 \\
\hline $\begin{array}{l}\text { Авага ажы-төлу артык, аңчыга } \\
\text { алды-киш артык }\end{array}$ & $\begin{array}{l}\text { Дорог охотнику соболь, а матери - сын, в } \\
\text { мученьях рожденный }\end{array}$ & A & 4,55 \\
\hline $\begin{array}{l}\text { Авт өлүр - баглаажы артар, ада } \\
\text { өлүр - оглу артар }\end{array}$ & $\begin{array}{l}\text { Конь падает }- \text { коновязь останется, отец } \\
\text { умрет - сын останется }\end{array}$ & MPC & 4,55 \\
\hline
\end{tabular}




\begin{tabular}{|l|l|c|c|}
\hline Авазы хүн болза, ачазы ай болур & Если солнце - мать, отец - луна & МЖРС & 4,55 \\
\hline
\end{tabular}

Прим.: значение средних оценок: от 5 до 4 - полностью согласен, от 2 до 1 - не согласен.

Наибольшую степень несогласия тувинцы молодого и зрелого возраста выразили с пословицами, отнесенными к шкалам: «Враждебный сексизм по отношению к женщинам» (ВСЖ), «Мужские роли в семье» (МРС), «Мужские и женские роли в семье» (МЖРС) (см. табл. 4).

Таблица 4. Пословицы с минимально выраженным согласием тувинцев молодого и зрелого возраста Table 4. Proverbs which get the lowest support from younger and older Tuvans.

\begin{tabular}{|c|c|c|c|}
\hline \multicolumn{2}{|c|}{ Тувинцыы молодого возраста (от 18 до 35 лет) } & \multirow{2}{*}{$\begin{array}{l}\text { Шкаль } \\
\text { ВСЖ }\end{array}$} & \multirow{2}{*}{$\begin{array}{c}\text { Ср. балл } \\
\text { 3,64 }\end{array}$} \\
\hline $\begin{array}{l}\text { Кыс кижи будун силгивес, халымак, } \\
\text { сиилеңзин көргүспес }\end{array}$ & $\begin{array}{l}\text { Девушке нельзя качать ногою, нельзя } \\
\text { показывать ветреность и распущенность } \\
\text { свою }\end{array}$ & & \\
\hline Сен дизе уруу, чемелезе кадайы & $\begin{array}{l}\text { Дочку свою ругает, лишь свою жену все } \\
\text { укоряет }\end{array}$ & MPC & 3,64 \\
\hline $\begin{array}{l}\text { Кыс кижи дөр бажынга олурбас, } \\
\text { төре херээ кылбас }\end{array}$ & $\begin{array}{l}\text { Женщина не садится на почетное место и } \\
\text { не решает государственные дела }\end{array}$ & ВСЖ & 3,65 \\
\hline $\begin{array}{l}\text { Өшку бажын тавакка салбас, кыс } \\
\text { кижиниң сөзун херекке албас }\end{array}$ & $\begin{array}{l}\text { Козьей головой не угощают, с бабьим } \\
\text { словом не считаются }\end{array}$ & ВСЖ & 3,72 \\
\hline $\begin{array}{l}\text { Иезин «инээм» дээр, адазын «аъдымм» } \\
\text { дээр. }\end{array}$ & $\begin{array}{l}\text { Мать сравнивают с коровой, а отца - с } \\
\text { конем }\end{array}$ & МЖРС & 3,73 \\
\hline $\begin{array}{l}\text { Авага ажы-төлу артык, аңчыга } \\
\text { алды-киш артык }\end{array}$ & $\begin{array}{l}\text { Дорог охотнику соболь, а матери - сын, в } \\
\text { мученьях рожденный }\end{array}$ & A & 3,82 \\
\hline \multicolumn{4}{|c|}{ Тувинцы зрелого возраста (от 36 лет и старше) } \\
\hline $\begin{array}{l}\text { Өшкү бажын тавакка салбас, кыс } \\
\text { кижиниң сөзүн херекке албас }\end{array}$ & $\begin{array}{l}\text { Козьей головой не угощают, с бабьим } \\
\text { словом не считаются }\end{array}$ & ВСЖ & 2,85 \\
\hline $\begin{array}{l}\text { Иезин «инээм» дээр, адазын «аъдымм» } \\
\text { дээр. }\end{array}$ & $\begin{array}{l}\text { Мать сравнивают с коровой, а отца - c } \\
\text { конем }\end{array}$ & МЖРС & 3,10 \\
\hline $\begin{array}{l}\text { Кыс кижи дөр бажынга олурбас, төре } \\
\text { херээ кылбас }\end{array}$ & $\begin{array}{l}\text { Женщина не садится на почетное место и } \\
\text { не решает государственные дела }\end{array}$ & ВСЖ & 3,11 \\
\hline $\begin{array}{l}\text { Даш октаан черинге чыдар, кыс } \\
\text { берген черинге орар }\end{array}$ & $\begin{array}{l}\text { Где камень бросил, там и он лежит, куда ты } \\
\text { отдал дочь - там ей век жить }\end{array}$ & ЭБ & 3,50 \\
\hline Сен дизе уруу, чемелезе кадайы & $\begin{array}{l}\text { Дочку свою ругает, лишь свою жену все } \\
\text { укоряет }\end{array}$ & MPC & 3,50 \\
\hline $\begin{array}{l}\text { Кыс кижи будун силгивес, халымак, } \\
\text { сиилеңзин көргұспес }\end{array}$ & $\begin{array}{l}\text { Девушке нельзя качать ногою, нельзя по- } \\
\text { казывать ветреность и распущенность } \\
\text { свою }\end{array}$ & ВСЖ & 3,65 \\
\hline
\end{tabular}

Прим.: значение средних оценок: от 5 до 4 - полностью согласен, от 2 до 1 - не согласен.

Список допустимых пословиц, у тувинцев зрелого возраста шире, чем у молодых тувинцев. Статистически значимые возрастные различия выявлены при оценивании пословиц:

Авага ажы-төлү артык, аңчыга алды-киш артык - 'Дорог охотнику соболь, а матери - сын, в мученьях рожденный’ (U=0,040), 
Эки аъдынны суглуктуг суггарып өрет, эки оглуңну кадыгк ишке дадыктыр - 'Хорошего коня с уздой пить учи, хорошего сына тяжелой работой закаляй' (U=0,042),

Кускун кара-даа болза, төлүнге ынак - 'Ворон, хоть черный, воронят своих любит' (U=0,044), где степень допустимости таких поступков выше в выборке респондентов зрелого возраста.

С такой пословицей, как: Өшкү бажын тавакка салбас, кыс кижиниң сөзүн херекке албас - 'Козьей головой не угощают, с бабьим словом не считаются’ ( $\mathrm{U}=0,013)$ - люди старшего поколения скорее не согласны, в отличие от молодых людей.

Тувинцы молодого возраста согласны с такой пословицей: Кежиглиг хемни үер үрээр, кежээ келинни хоп үрээр - ‘Половодье крепкий берег размывает, оговор на грех невестку подбивает’ (U=0,020).

У молодых тувинцев высокие значения получились по шкалам: «Традиционная женственность» и «Традиционная мужественность», а низкие значения по шкале «Враждебный сексизм по отношению к женщинам». У респондентов старшего поколения наиболее высокие оценки были даны по шкалам: «Андроцентризм» $(\mathrm{U}=0,043)$, а также по шкале «Традиционная мужественность», и низкие значения по шкале «Враждебный сексизм по отношению к женщинам» $(\mathrm{U}=0,046)$, хотя средние значения по этой шкале находятся скорее на уровне допустимости, чем несогласия.

Таким образом, статистически значимых половых и возрастных различий в оценке пословиц, отражающих гендерные стереотипы, в выборке тувинцев не выявлено. Большинство опрошенных тувинцев считают вполне допустимыми традиционные представления о мужественности и женственности. В отличие от женщин, мужчины и люди старшего поколения в целом согласны с сексистскими пословицами в отношении женщин. Можно отметить, что отраженные в пословицах традиционные представления о мужском и женском поведении в целом принимаются и соблюдаются в межполовых отношениях современных тувинцев.

\section{Заключение}

В целом в паремиях тувинцев достаточно подробно отражено содержание и четко прослеживается скрытая направленность гендерных стереотипов. В паремиях тувинского народа отражены традиционные семейно-родовые отношения, основанные на патриархальных установках, регламентации гендерных различий и дихотомизации мужского и женского. Несмотря на наличие тенденции к андроцентричности, идеи о неравенстве полов, обычаи и запреты экзогамного брака встречаются у тувинцев не так часто. В тувинских пословицах преобладают интенции: «Восхваление», «Оценка», «Наставление», «Совет», «Обличение». В мужских стереотипах тувинцев преобладают интенции: «Восхваление», «Наставление», «Оценка», а женские стереотипы связаны с интенциями «Предостережение», «Обличение», «Наставление», «Упрек».

Большинство опрошенных тувинцев выражают согласие с пословицами, отражающими традиционные представления о мужском и женском поведении, в целом разделяют пословицы с сексистскими установками в отношении женщин. Данные тенденции особенно выражены у мужчин и у людей старшего поколения.

\section{СПИСОК ЛИТЕРАТУРЫ}

Байжанова, Н. Р. (2004) Метафорические образы, характеризующие человека, в алтайских пословицах (в сопоставлении с тувинскими) // Языки коренных народов Сибири / отв. ред. Н. Б. Кошкарёва, Н. Н. Широбокова, А. Р. Тазранова. Вып. 14. Новосибирск : НГУ. 236 с. С. 60-72.

Берн, Ш. (2007) Гендерная психология. Законы мужского и женского поведения. СПб. : ПраймЕврознак. 318 с.

Доржу, 3. Ю. (2019) Межэтническое взаимодействие русских и тувинцев в советской и постсоветской Туве (на примере национально-смешанных семей) [Электронный ресурс] // Новые исследования Тувы. № 1. URL: https://nit.tuva.asia/nit/article/view/835 (дата обращения: 11.03.2019). DOI: 10.25178/ nit.2019.1.11

Дьон-сэргэ ох тыла (2001) (Тыва өһүн хоһоонноро, ох тыллара) [Тувинские пословицы, меткие изречения] / под ред. Н. И. Сафронова. Якутск : Бичик. 40 с. (На як. яз.).

Егорова, А.И., Чочкина, М.П., Сарбашева, С.Б. (2019) Психолингвистический анализ гендерных стереотипов в алтайских и якутских пословицах // Томский журнал лингвистических и антропологических исследований. № 2. С. 51-63. DOI: 10.23951/2307-6119-2019-2-51-63 
Калзан, А. К. (1955) Тувинские народные пословицы и поговорки. Кызыл : Тувинское книжное издательство. 55 с.

Кенин-Лопсан, М. Б. (1987) Обрядовая практика и фольклор тувинского шаманства конца XIX нач. ХХ в. Новосибирск : Сибирское отделение. 162 с.

Кирилина, А. В. (1999) Гендер: лингвистические аспекты. М. : Институт социологии РАН. 189 с.

Клёцина, И. С. (2009) Гендерная психология. СПб. : Питер. 496 с.

Курбатский, Г.Н. (2001) Тувинцы в своем фольклоре. Кызыл : Тувинское книжное издательство. 464 с.

Маннай-оол, М. (2002) Обычаи тувинского народа // Ученые записки. Вып. 19. Кызыл : ТИГИ. 326 с. C. $52-59$.

Орус-оол, С. М. (1997) Тувинские героические сказания. Новосибирск : Наука. 479 с.

Очерки тувинского фольклора = Тыва улустуң аас чогаалы (1976) / Куулар, Д. С., Гребнев, Л. В., Калзан, А. К. и др. Кызыл : Тувинское книжное издательство. 146 с.

Потапов, Л. П. (1973) Умай - божество древних тюрков в свете этнографических данных // Тюркологический сборник / отв. ред. А. Н. Кононов. М. : Наука. 412 с. С. 265-286.

Телия, В. Н. (1996) Русская фразеология. Семантический, прагматический и лингвокультурологический аспекты. М. : Языки славянской культуры. 289 с.

Хадаханэ, М., Саган-оол, О. (1966) Тувинские пословицы и поговорки / сост. М. Хадаханэ, О. Саганоол. Кызыл : Тувинское книжное издательство. 77 с.

Хертек, Я. Ш. (1985) Русско-тувинский фразеологический словарь. Кызыл : Тувинское книжное издательство. 299 с.

Best, D. L. (2001) Gender Concepts: Convergence in Cross-Cultural Research and Methodologies // CrossCultural Research. № 1. P. 23-43.

Lease, S. H., Montes, S. H., Baggett, L. R., Sawyer, J., Fleming-Norwood, K. M., Hampton, A. B., Ovrebo, E., Ciftci, A., Boyraz, G. (2012) A Cross-Cultural Exploration of Masculinity and Relationships in Men From Turkey, Norway, and the United States // Journal of Cross-Cultural Psychology. № 6. P. 84-105.

Williams, J. E., Best, D. L., Haque, A., Pandey, J., Verma, R. K. (1982) Sex-trait stereotypes in India and Pakistan // Journal of Psychology. № 111. P. 167-181.

Дата поступления: 11.03.2019 2.

\section{REFERENCES}

Baizhanova, N. R. (2004) Metaforicheskie obrazy, kharakterizuiushchie cheloveka, v altaiskikh poslovitsakh (v sopostavlenii s tuvinskimi) [Metaphorical characteristics of people in Altai proverbs (in comparison with Tuvan)]. In: Iazyki korennykh narodov Sibiri [Indigenous languages of Siberia] / ed. by N. B. Koshkareva, N. N. Shirobokova and A. R. Tazranova. Vol. 14. Novosibirsk, NGU. 236 p. Pp. 60-72. (In Russ.).

Bern, Sh. (2007) Gendernaia psikhologiia. Zakony muzhskogo i zhenskogo povedeniia [The Social Psychology of Gender]. Transl. from Engl. St. Petersburg, Praim-Evroznak. 318 p. (In Russ.).

Dorzhu, Z. Yu. (2019) Interethnic interaction of Russian and Tuvans in Soviet and Post-Soviet Tuva: the case of ethnically mixed families. The New Research of Tuva, no. 1. URL: https://nit.tuva.asia/nit/article/ view/835 (access date: 11.03.2019). (In Russ.). DOI: 10.25178/nit.2019.1.11

D'on-serge okh tyla (Tyva öhün khohoonnoro, okh tyllara) [Tuvan proverbs and witty sayings] (2001) / ed. by N. I. Safronova. Yakutsk, Bichik. 40 p. (In Yakut).

Egorova, A. I., Chochkina, M. P. and Sarbasheva, S. B. (2019) Psikholingvisticheskii analiz gendernykh stereotipov v altaiskikh i iakutskikh poslovitsakh [Psycholinguistic analysis of gender stereotypes in Altai and Yakut proverbs]. Tomsk Journal of Linguistics and Anthropology, no. 2, pp. 51-63. (In Russ.) DOI: 10.23951/23076119-2019-2-51-63

Kalzan, A. K. (1955) Tuvinskie narodnye poslovitsy i pogovorki [Tuvan folk proverbs and sayings]. Kyzyl, Tuvan book publishing house. 55 p. (In Russ.).

Kenin-Lopsan, M. B. (1987) Obriadovaia praktika i fol'klor tuvinskogo shamanstva. Konets XIX - nachalo $X X v$. [Ritual practice and folklore of Tuvinian shamanism. Late XIX - early XX century]. Novosibirsk, Nauka. 165 p. (In Russ.). 
Kirilina, A. V. (1999) Gender: lingvisticheskie aspekty [Gender: linguistic aspects]. Moscow, Institut sotsiologii RAN. 189 p. (In Russ.).

Kletsina, I. S. (2009) Gendernaia psikhologiia [Gender psychology]. St. Petersburg, Piter. 496 p. (In Russ.).

Kurbatskii, G. N. (2001) Tuvintsy $v$ svoem fol'klore (istoriko-etnograficheskie aspekty tuvinskogo fol'klora) [Tuvans in their folklore: Historical and ethnographic aspects of Tuvan folklore]. Kyzyl, Tuvan book publishing house. 464 p. (In Russ.).

Mannai-ool, M. (2002) Obychai tuvinskogo naroda [Customs of Tuvan people]. In: Uchenye zapiski, vol. 19. Kyzyl, TIGI. 326 p. Pp. 52-59. (In Russ.).

Orus-ool, S. M. (1997) Tuvinskie geroicheskie skazaniia [Tuvan heroic legends]. Novosibirsk, Nauka. 479 p. (In Russ.).

Ocherki tuvinskogo fol'klora = Tyva ulustung aas chogaaly [Essays on Tuvan folklore] (1976) / Kuular, D. S., Grebnev, L. V., Kalzan, A. K. et al. Kyzyl, Tuvan book publishing house. 146 p. (In Russ.).

Potapov, L. P. (1973) Umai - bozhestvo drevnikh tiurkov v svete etnograficheskikh dannykh [Umai, the deity of the ancient Türks, in the light of ethnographic data]. In: Tiurkologicheskii sbornik / ed. by A. N. Kononov. Moscow, Nauka. 412 p. Pp. 265-286.

Teliia, V. N. (1996) Russkaia frazeologiia. Semanticheskii, pragmaticheskii i lingvokul'turologicheskii aspekty [Russian phraseology. Semantic, pragmatic and linguocultural aspects]. Moscow, Yazyki slavianskoi kul'tury. 289 p. (In Russ.).

Khadakhane, M. and Sagan-ool, O. (1966) Tuvinskie poslovitsy i pogovorki [Tuvan proverbs and sayings] / comp. by M. Khadakhane and O. Sagan-ool. Kyzyl, Tuvan book publishing house. 77 p. (In Russ.).

Khertek, Ia. Sh. (1985) Russko-tuvinskii frazeologicheskii slovar' [A Russian-Tuvan phraseological dictionary]. Kyzyl, Tuvan book publishing house. 299 p. (In Russ. And Tuv.).

Best, D. L. (2001) Gender Concepts: Convergence in Cross-Cultural Research and Methodologies. CrossCultural Research, no. 1, pp. 23-43.

Lease, S. H., Montes, S. H., Baggett, L. R., Sawyer, J., Fleming-Norwood, K. M., Hampton, A. B., Ovrebo, E., Ciftci, A. and Boyraz, G. (2012) A Cross-Cultural Exploration of Masculinity and Relationships in Men From Turkey, Norway, and the United States. Journal of Cross-Cultural Psychology, no. 6, pp. 84-105.

Williams, J. E., Best, D. L., Haque, A., Pandey, J. and Verma, R. K. (1982) Sex-trait stereotypes in India and Pakistan. Journal of Psychology, no. 111, pp. 167-181.

Submission date: 11.03.2019. 